Analysis of issues of interest in unification economic cooperation by visualizing big data on social networks

\title{
Analysis of issues of interest in unification economic cooperation by visualizing big data on social networks
}

\author{
Ugsun Hwang*
}

\begin{abstract}
This study aims to intuitively identify trends in public interest by performing visualization analysis on unification economic cooperation using social network user opinion big data. For the "Unification Economic Cooperation" big data, the related big data were extracted using the Textom analysis tool, and text mining was performed. The results were expressed as a visualization figure.

The results showed that, first, social network users were interested in North Korea's regional agricultural planning and education by the US and the government. Additionally, North Korea's rural villages existed in connection with pastoral and missionary words. An interest in how North and South Korea cooperate in investment and development in rural areas was identified. Second, there was an issue of interest in housing exchange and cooperation in North Korean villages by the community of club members as words such as club members $\rightarrow$ housing, common $\rightarrow$ housing, village $\rightarrow$ community exchange $\rightarrow$ cooperation were connected. Third, users were interested in culture and art. It would be useful to find and implement economic cooperation, a link between culture and art connected with North Korea's economic cooperation. Fourth, words such as technology, research, development, and dissemination were drawn as issues of interest. From the perspective of an integrated process, it is of interest to the general public to identify ways to implement it so that it can be pursued with economic benefits for both South and North Korea. Fifth, social network users were interested in the content of dot-com sites. The importance of the promotion of unification economic cooperation through these dot-com sites was confirmed.
\end{abstract}

Keywords : unification economic cooperation, big data, community of club members, dot-com site, investment development in rural areas

* (First Author) Halla University, Department of Business Administration, Professor, yesek41@naver.com, https://orcid.org/0000-0002-9443-7910 


\section{I . 남북 협력 변화와 빅데이터}

과거부터 남 - 북한의 관계는 국가의 정책과 국제정세, 북한의 환경과 대응 등에 의하여 냉 - 온 탕의 계속적인 변화가 발생하고 있다. 특히 2018년 이후 남 - 북한의 경제협력은 서로 간의 정치적 인 이해관계와 연결되어 경제협력 상황이 급변하고 있다. 2017년에는 북한의 비핵화를 위하여 UN 대북제재가 시작되었으며, 이를 해결하기 위하여 2018년의 남북정상회담, 2019년까지 2차례의 북미 정상회담 등이 이루어졌다. 그리고 한반도 신경제 구상과 연계되는 경제협력 등으로 남북한 철도 및 도로 연결, 금강산관광 사업재개, 개성공단 협력사업 활성화 등에 대한 추진의지가 표명되기도 하였다. 그러나 2019년 비핵화 경제협력을 위한 북미 정상회담은 결렬되었고, 남북관계는 과거로 회귀되었다. 최근 북한경제는 가중되는 국제적인 대북경제제재와 홍수 등 자연재해로 막심한 피해 를 받았으며, 대외무역은 코로나 바이러스 사태로 거의 제로 상태로 떨어졌다. 북한은 매우 긴박한 경제 상황에 놓여 있기 때문에 대외적인 경제적 돌파구가 필요한 상황이다. 이러한 위기상황은 오 히려 남북경협을 선택할 좋은 기회가 될 수도 있다.1) 그리고 수출 의존형의 남한경제는 최근 코로 나로 인한 급속한 세계경제의 하락으로 수출과 내수 부진이 진행되고 있어 상생 측면에서 남북한 경제협력의 필요성이 강하게 대두되고 있다.

통일경제협력 관련 연구는 전문가에 의한 이론 연구, 각종 자료 분석에 의한 실태조사 연구 및 설문 조사 연구 등으로 여러 형태도 지속적으로 진행되어 왔다. 이러한 연구 중에서 실태조사 연구, 설문조사 연구는 직 - 간접적으로 실제 상황에 근거하였기 때문에 현실적이라 할 수 있다. 설문조 사 연구는 직접적인 피험자를 대상으로 하기 때문에 현실적인 영향 요소를 발견할 수 있는 장점이 존재한다. 그러나 설문조사 연구는 제한된 연구대상에게 질문하여 분석하였기 때문에 일반화하기 에는 미흡하다. 많은 연구대상의 응답에 의한 분석은 연구결과의 현실화 가능성을 높일 수 있다. 따라서 일반 대중의 의견을 반영하는 연구가 더 큰 유용성을 나타낼 수 있는 것이다. 그리하여 다 수가 공감할 수 있는 남북경협 논의의 출발점(Lee, Y. H., 2019)을 도출할 수 있는 연구가 필요하다.

특히, 소셜 네트워크에서 일반 대중들이 자유롭게 의견을 게시하여 많은 데이터를 포함하는 빅 데이터의 성격을 갖고 있다. 이런 의미에서 본 연구의 주제인 통일경제협력에 관한 소셜 네트워크 분석접근은 일반 대중들의 관심사를 포함한 내용에 대한 의견분석에 대한 실질적인 제안이 될 것 이다. 이 같은 일반 대중들의 의견 반영 과정은 통일경제협력 정책을 활성화할 수 있는 방안수립에 효과적인 대안으로 활용될 수 있을 것이다. 또한, 본 연구는 분석결과를 시각적으로 도형화하여 도 표에 의한 결과 제시보다 연구자와 일반 대중의 이해도를 높이는데 주안점을 두었다. 따라서 본 연 구의 목적은 소셜 네트워크 이용자 의견 빅데이터를 활용하여 통일경제협력에 관한 시각화분석을 함으로써 직관적인 일반 대중의 관심 트랜드를 파악하는 것이다. 이 결과는 일반 대중들이 실질적

1) 조건식(2020). 기로에선 북한경제, 남북경협은 어디로? 한백통일경제연구, 창간호, p. 6. http://www.hineri.org/board/ download.php?b_id=seminar\&num=2\&n=0 
으로 통일 경제협력의 내용에 어떠한 관심을 가지고 있는지의 관심 이슈를 도출하게 함으로써 통 일 경제협력 정책에 반영할 수 있는 시사점을 제공할 것이다.

\section{․ 남북 협력 변화와 빅데이터}

\section{1 남북 경제협력 변화와 방향}

남북한 간의 경제와 교류협력의 분위기는 2018년 4월 27일 판문점 선언을 시작으로, 5.26, 9.18 남북정상회담 등을 통하여 개선되었다.2) 그리하여 한반도 신경제 구상에 의한 경제협력, 남북 간 철도 및 도로 연결 현대화 사업, 금강산 관광 재개 등의 남북교류 협력 사업이 실행되고 있었다. 그러나 2019년 하노이 북미 정상회담이 결렬되어 경색단계로 변화되면서, 통일을 위한 경제협력은 중단된 것이다. 이와같이 남북 경제협력은 과거부터 중단과 재개를 반복하고 있다고 할 수 있다. 이러한 행태는 한반도 평화프로세스를 위하여 계속 시도될 수밖에 없다. 즉 한반도의 정치 - 군사 적 긴장을 완화하고 통일비용의 감소와 남한 경제의 재도약을 위한 경제적 통합의 필요성을 바라 는 정책적 수요와 맞물려 지속될 것으로 보인다(Kim, B. S. et al., 2018). 또한, 북한은 미국의 경제 제재 압박으로 대 - 내외적으로 심각한 상황이기 때문에 경제적 해결을 생각하고 있을 것이다.

Lee, G. Y. et al.(2019)는 남북관계가 개선되었을 경우를 전제로 주민 1,000명을 대상으로 DMZ 과 접경지역의 지속가능한 발전 방향을 설문조사 한 결과 경제적 가치가 $17 \%$ 로 나타났다. Kim and Choi(2012)는 북한이탈주민 780명을 대상으로 설문조사한 결과, 인도주의 지원에 대해서는 남 한 주민들이 분배의 투명성과 퍼주기 논쟁 등의 영향으로 다른 사안보다 부정적인 견해를 갖고 있 는 것으로 파악되었다. 그러나 북한에 대한 남한의 경제투자를 북한 주민들이 어떻게 받아들이고 있다고 생각하십니까?”라는 질문에 ‘긍정적으로 생각할 것이다'라고 답한 비율은 $79.3 \%$ 로 가장 많 은 반면, ‘부정적으로 생각할 것이다'라는 응답은 $4.5 \%$ 로 매우 적었다. 북한의 입장에서도 대북지 원보다는 대북투자에 의한 상생협력을 원하고 있는 것이다.

따라서 Park(2019)는 지속가능한 남북경제협력 방안으로 남북이 함께 일하며 공동의 생산적 가 치를 만들어낼 수 있는 길로 나아가야 하는데, 그 길은 경협뿐이며 '상생경협, '동반부국' 의 단어 를 주장하였다. 그리고 평화자동차를 사례 분석하였다. 이처럼 통일을 위한 경제협력은 한반도의 정치 - 군사적 상황과는 관계없이 지속적으로 이루어져야 한다. 이러한 관점에서 이론적 분석에 의 하여 통일을 위한 한반도 신경제구상 경제통합을 위하여, 국제화를 통한 비핵화, 특구를 통한 제도 화, 시장화를 통한 밑으로부터의 체제이행 등이 유용하다.3)

2) 백성호(2020). 남북한 해운산업의 협력 전망과 과제. 한백통일경제연구, (2020), 창간호, p. 180. http://www.hineri. org/board/download.php?b_id=seminar\&num $=2 \& n=0$ 
남북경협에 의한 대북투자는 서로 간의 일반 대중의 관심 주제에 집중하는 것이 향후 지속적이 고 성공확률을 높일 수 있을 것이다. 왜냐하면 서로 관심을 가지는 경제생활 관련 분야의 협력은 기본 생활과 관계되기 때문에 남북 경색과정에도 남북 대중 모두의 관심 이슈로 나타나 중단하기 쉽지 않을 것이다. 일반 대중들이 관심을 가지는 분야에 대한 지속적인 경제협력의 단절은 남북 경 색국면, 전쟁위협 등의 위험한 상황을 초래할 수 있다. 통일을 위한 남북 경제협력은 일반 대중들로 부터 그 요소를 추출하는 것이 가장 유용할 것이다. 하지만 북한 일반 대중의 의도는 실질적으로 파악할 수 없기 때문에, 다수의 남한 일반대중 입장을 반영하는 요소를 추출하여 북한이 원하는 분 야와의 경제협력으로 접근하는 방법이 필요하다. 이러한 방법은 기존의 연구에서도 다양한 방법으 로 분석되어 왔다. 하지만 연구대상의 한계로 미흡하였다. 즉 선행연구에서는 연구자가 피험자를 선택하여 설문조사를 실행한 연구, 전문가들에 의한 실태조사, 이론연구 등으로 이루어졌다. 수많 은 일반 대중의 생각이 반영되는 연구는 미흡하여 직접적인 일반 대중의 생각이 포함된 연구가 필 요하다.

일반 대중의 의견은 각 개인들이 소셜 네트워크에 의한 인터넷에 의하여 표현되며 방대하므로 빅데이터라고 한다. 이 데이터가 체계적으로 분석된다면 인터넷 이용자들에 의한 실질적 의견으로 가장 현실적인 정보가치가 될 것이다. 비핵화에 따른 경제협력 이슈를 빅데이터로 분석하였다. 하 지만 이 연구는 비핵화를 전제한 경제협력 분석이다.4) 그러나 비핵화는 일반 대중의 의견보다는 복잡한 정치적 관계성이 내포되어 경제협력과 연결되면 경제협력에 집중할 수 없게 되는 것이다. 그러므로 비핵화를 제외한 순수한 통일경제협력의 관점에서 일반 대중 관심 빅데이터를 분석하면 더욱 유용할 것이다. 남북한 통일경제협력의 노력이 활성화되면서 비핵화를 논의하는 아래로부터 위로의 방법으로 실마리를 풀어가는 방법을 찾는 것이다. 빅데이터는 설문이나 심층 인터뷰 등의 연구방법에서 나타나는 연구대상의 한계를 극복하여 수많은 대중의 의견을 포함하기 때문에 일반 화 유용성이 더 크다고 할 수 있다. 아울러 일반 대중들이 쉽게 공감할 수 있는 도형화에 의한 분석 은 이해의 폭을 넓게 하여 가치가 상승할 것이다.

\section{2 빅데이터 적용 및 시각화}

빅데이터는 양적으로 매우 크기 때문에 숫자나 텍스트로 표현하는 것보다 차트, 그림, 이미지 등 으로 시각적인 표현을 하면 더욱 유용할 것이다(Kim \& Lee, 2020; Hwang, 2018a). 그러나 통일 분야에서는 빅데이터 시각화 연구가 거의 존재하지 않고 있다. 데이터 시각화는 데이터들 간의 관

3) 김병연, 박상인, 최연태(2018). 남북 경제협력과 경제공동체, 시장과정부 연구센터 보고서. pp. 1-82. https://rcmg.snu.ac.kr/ko/board/Publications/view/161/download/118

4) 손은영, 황태준(2018). 비핵화에 따른 남북 경제협력 이슈 분석-빅데이터 분석을 중심으로 통일부 통일교육원 논문집, pp. 125-160. https://www.uniedu.go.kr/uniedu/home/pds/pdsatcl/view.do?id=20049\&mid=SM00000532 
계를 정보구조나 패턴으로 쉽게 찾아낼 수 있도록 한다(Byun \& Park, 2016). 데이터 시각화는 가 공하지 않고 나열된 데이터를 표나 그림 형태로 나타내 주는 과정이다. 빅데이터의 시각화는 $2 \mathrm{D}$ 또는 3D로 표현되기도 한다(Keim, $\mathrm{Qu}, \& \mathrm{Ma}, 2013)$. 따라서 시각화는 빅데이터의 복잡한 내용을 알기 쉽게 표현한다. 시각화 표현은 공급자 입장에서 고객이 요구하는 니즈에 대하여 더욱 쉽게 직 관적으로 대처할 수 있도록 한다. 즉 사용자 그룹별 맞춤 콘텐츠를 제공하거나, 마케팅을 위한 고객 관계관리(CRM: Customer Relationship Management)의 기초 자료로 활용할 수 있다(Baran, 2011). 최근에는 빅데이터를 직관적으로 살펴볼 수 있도록 돕는 시각화 기술이 중요해지고 있다(Choe, $\mathrm{Ham}, \& \mathrm{Kim}, 2013)$. 시각화를 위한 기술은 독자적인 프로그래밍에 의하여 표현하는 방법도 존재 하지만, 개발자의 주관성이 포함되기 때문에 표준화의 문제가 나타난다. 그리하여 기업이나 조직단 체에서 정형적인 플랫폼에 의하여 표준화하여 구축된 빅데이터 시각화 도구가 개발 및 활용되는 비중이 크다(Hwang, 2018b). 빅데이터 시각화 도구에는 네이버 데이터 랩, 다음 소셜 매트릭스, SAS Visual Analytics, 구글 트랜드, R 패키지, 빅데이터 분석도구 공급업체 개발 시각화 도구 등 이 존재한다.

본 연구에서는 빅데이터 시각화를 위하여 텍스톰(Textom) 프로그램 분석도구를 사용하였다. 이 분석 도구는 개인에 의한 주관적인 프로그램이 아니라 빅데이터 분석을 위하여 정형화된 프레임에 의한 소프트웨어이기 때문에 데이터의 추출은 객관적인 신뢰성이 존재한다고 할 수 있다(Hwang, 2018b, p. 166).

\section{III. 자료 및 데이터 수집과 분석방법}

\section{1 자료수집 및 분석방법}

본 연구에서는 통일경제협력에 관한 대중들의 관심 트랜드를 조사하기 위하여 트위터, 페이스북, 다음(Daum)과 네이버 포털의 뉴스, 지식, 블로그, 카페 등의 데이터를 활용하였다. 통일경제협력 데이터는 빅데이터 도구 텍스톰(Textom)에 의하여 분석하였다. 텍스톰(Textom)은 텍스트마이닝 기술을 이용한 빅데이터 분석 솔루션으로 웹 환경에서 데이터를 수집, 정제하며 매트릭스 데이터 생성까지 처리할 수 있으며 웹, 소셜 네트워크, 보유데이터 분석이 가능하다.5) 텍스톰(Textom) 분 석 도구의 프로그램 검색어에는 “통일경제협력” 키워드를 입력하였다. 분석 도구에서는 관련 빅데 이터 자료를 추출하고 텍스트마이닝(textmining) 정제를 실행하였다. 텍스톰(Textom) 분석 도구는 트위터, 카페 등에서 나타나는 비정형적인 내용에 대하여도 키워드를 자동으로 정제하여 나타낸다. 
정제결과는 소셜 네트워크상에서 주요 핵심단어들이 얼마나 많이 검색되었는가를 나타내기 때문 에 빈도비율이 높은 단어에 해당할수록 중요성이 높다는 것을 나타낸다(Hwang, 2017). 빅데이터 결과는 시각화된 도형에 의하여 표현된다. 시각화 결과는 워드클라우드, 네트워크 차트, 에고 네트 워크, 메트릭스 차트 등으로 명명되어 형상화한다. 형상화된 표현들은 통일경제협력에 대한 빅데이 터 시각화 내용을 나타낸다.

\section{2 데이터 수집}

빅데이터는 2020년 1월 1일부터 2020년 12월 31일까지 1년 동안 네이버(뉴스, 카페, 지식인), 다 음(뉴스, 카페, 지식인), 구글(웹, 뉴스), 트위터 등의 소셜 네트워크 내용을 수집하였다. 북한 경제 협력 관련 데이터는 네이버 2,091개, 다음 1,955 개, 구글 250 개, 트위터 38 개가 도출되었다. 이 데이 터들은 텍스톰(Textom) 프로그램에서 자동으로 1,000 개가 1 차 정제한다.

도출된 결과는 인터뷰 대상자들의 인터뷰를 통해 “이후, 곳, 차, 전, 보" 등의 의미가 없는 내용 을 제외하고, 2 차 정제를 실행하여 200개 단어를 추출하였다. 분석도구 텍스톰(Textom)에서 2 차 정제 단어를 200개로 한정한다. 분석절차는 Figure 1과 같다.

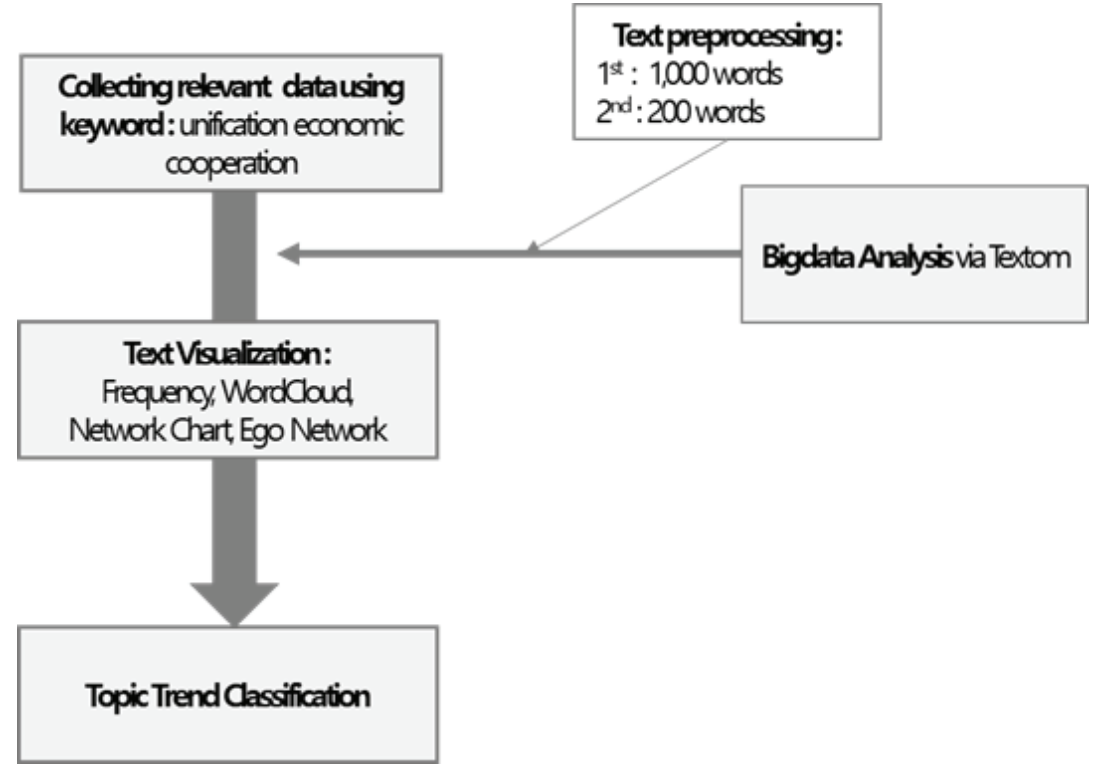

$<$ Figure 1> Analytic procedure 


\section{IV. 시각화 결과분석}

\section{1 주요단어 빈도분석 결과}

2차 정제 단어는 최종적으로 100 개의 주요 단어로 축약되었다. 그 결과는 다음과 같다.

$<$ Table 1> Most frequent words in contents of unification economic cooperation

\begin{tabular}{|c|c|c|c|c|c|c|c|}
\hline Rank & Word & Frequency & $\%$ & Rank & Word & Frequency & $\%$ \\
\hline 1 & 지역 & 21,278 & 3.85 & 51 & 강화 & 3,909 & 0.71 \\
\hline 2 & 농업 & 18,222 & 3.30 & 52 & 규모 & 3,861 & 0.70 \\
\hline 3 & 농촌 & 17,747 & 3.21 & 53 & 교류 & 3,781 & 0.68 \\
\hline 4 & 정부 & 14,363 & 2.60 & 54 & 단체 & 3,769 & 0.68 \\
\hline 5 & 미국 & 13,487 & 2.44 & 55 & 영국 & 3,748 & 0.68 \\
\hline 6 & 서울 & 13,433 & 2.43 & 56 & 센터 & 3,676 & 0.67 \\
\hline 7 & 사회 & 12,707 & 2.30 & 57 & 보호 & 3,594 & 0.65 \\
\hline 8 & 닷컴 & 12,658 & 2.29 & 58 & 자원 & 3,578 & 0.65 \\
\hline 9 & 교육 & 11,963 & 2.17 & 59 & 자연 & 3,544 & 0.64 \\
\hline 10 & 대통령 & 11,774 & 2.13 & 60 & 안전 & 3,418 & 0.62 \\
\hline 11 & 뉴시스 & 11,426 & 2.07 & 61 & 투자 & 3,399 & 0.62 \\
\hline 12 & 개발 & 11,390 & 2.06 & 62 & 전략 & 3,384 & 0.61 \\
\hline 13 & 중국 & 9,900 & 1.79 & 63 & 미래 & 3,276 & 0.59 \\
\hline 14 & 문화 & 9,876 & 1.79 & 64 & 유럽 & 3,243 & 0.59 \\
\hline 15 & 관련 & 9,450 & 1.71 & 65 & 농산물 & 3,232 & 0.59 \\
\hline 16 & 운동 & 8,839 & 1.60 & 66 & 건강 & 3,154 & 0.57 \\
\hline 17 & 계획 & 8,529 & 1.54 & 67 & 평가 & 3,125 & 0.57 \\
\hline 18 & 세계 & 8,442 & 1.53 & 68 & 환자 & 3,124 & 0.57 \\
\hline 19 & 도시 & 8,411 & 1.52 & 69 & 독일 & 3,113 & 0.56 \\
\hline 20 & 마을 & 8,373 & 1.52 & 70 & 프로그램 & 3,110 & 0.56 \\
\hline 21 & 관광 & 7,532 & 1.36 & 71 & 한국일보 & 3,109 & 0.56 \\
\hline 22 & 환경 & 7,366 & 1.33 & 72 & 마음 & 3,084 & 0.56 \\
\hline 23 & 연구 & 7,344 & 1.33 & 73 & 기본 & 3,023 & 0.55 \\
\hline 24 & 산업 & 7,296 & 1.32 & 74 & 요구 & 3,001 & 0.54 \\
\hline 25 & 기술 & 6,791 & 1.23 & 75 & 체험 & 2,929 & 0.53 \\
\hline 26 & 일본 & 6,663 & 1.21 & 76 & 조성 & 2,905 & 0.53 \\
\hline 27 & 추진 & 6,530 & 1.18 & 77 & 프랑스 & 2,874 & 0.52 \\
\hline 28 & 시설 & 6,132 & 1.11 & 78 & 연합뉴스 & 2,854 & 0.52 \\
\hline 29 & 주민 & 6,007 & 1.09 & 79 & 가족 & 2,846 & 0.52 \\
\hline
\end{tabular}




\begin{tabular}{c|c|c|c|c|c|c|c}
\hline 30 & 공동 & 5,847 & 1.06 & 80 & 경기 & 2,843 & 0.51 \\
\hline 31 & 공동체 & 5,770 & 1.04 & 81 & 영향 & 2,779 & 0.50 \\
\hline 32 & 생산 & 5,633 & 1.02 & 82 & 과학 & 2,777 & 0.50 \\
\hline 33 & 금지 & 5,505 & 1.00 & 83 & 건설 & 2,745 & 0.50 \\
\hline 34 & 생명 & 5,348 & 0.97 & 84 & 체제 & 2,708 & 0.49 \\
\hline 35 & 교회 & 5,266 & 0.95 & 85 & 공개 & 2,650 & 0.48 \\
\hline 36 & 위원회 & 5,051 & 0.91 & 86 & 활성 & 2,641 & 0.48 \\
\hline 37 & 주택 & 4,765 & 0.86 & 87 & 입장 & 2,614 & 0.47 \\
\hline 38 & 기업 & 4,756 & 0.86 & 88 & 설명 & 2,607 & 0.47 \\
\hline 39 & 결과 & 4,748 & 0.86 & 89 & 대회 & 2,581 & 0.47 \\
\hline 40 & 역사 & 4,671 & 0.85 & 90 & 협동조합 & 2,579 & 0.47 \\
\hline 41 & 한국네티즌본부 & 4,329 & 0.78 & 91 & 현장 & 2,558 & 0.46 \\
\hline 42 & 학교 & 4,284 & 0.78 & 92 & 성공 & 2,549 & 0.46 \\
\hline 43 & 한겨레 & 4,247 & 0.77 & 93 & 인천 & 2,484 & 0.45 \\
\hline 44 & 복지 & 4,223 & 0.76 & 94 & 해외 & 2,462 & 0.45 \\
\hline 45 & 상황 & 4,124 & 0.75 & 95 & 전문 & 2,454 & 0.44 \\
\hline 46 & 발표 & 4,066 & 0.74 & 96 & 육성 & 2,445 & 0.44 \\
\hline 47 & 여성 & 3,969 & 0.72 & 97 & 공유 & 2,425 & 0.44 \\
\hline 48 & 식품 & 3,956 & 0.72 & 98 & 시행 & 2,421 & 0.44 \\
\hline 49 & 생각 & 3,948 & 0.71 & 99 & 구축 & 2,419 & 0.44 \\
\hline 50 & 전국 & 3,916 & 0.71 & 100 & 행정 & 2,414 & 0.44 \\
\hline & & & & & & \\
\hline
\end{tabular}

Table 1에 ‘지역', ‘농업’, ‘농촌', ‘정부’, ‘미국', ‘서울’ ‘사회’ ‘닷컴’ ‘교육’, ‘대통령’, ‘뉴시스, ‘개발', ‘중국', ‘문화' ‘관련', ‘운동', ‘계획', ‘세계’, ‘도시’, ‘마을' 등이 최상위 순위에 나타났다. 소 셜 네트워크 이용자들은 북한의 농촌지역의 농업에 대하여 우선적인 관심을 가지고 있다는 것이다. 또한 뉴시스6) 닷컴 언론 미디어는 한국 정부와 미국의 관련 계획에 대하여 주시하고 있다. 그리고 북한은 중국과 관련하여 경제협력 개발과 문화 관련 계획, 세계의 도시 마을 등에서 어떠한 운동 등을 하고 있는지에 대한 이슈에 관심을 나타냈다.

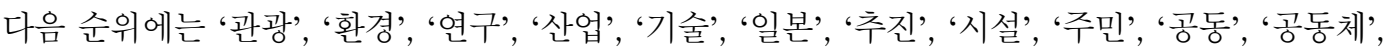
‘생산', ‘금지’, ‘생명', ‘교회', ‘위원회’, ‘주택', ‘기업', ‘결과', ‘역사' 등의 단어가 차지하고 있다. 이 것은 북한과 공동에 의한 관광, 산업, 환경, 시설, 기술 등의 생산추진에 대한 연구, 일본과 주민들의 반응 등이 궁금하다는 것을 나타낸다. 기업이 교회와 북한 관련 위원회 등으로 주택, 생명 등에 지 원할 때 역사적으로 금지해 온 결과 내용에 대한 이슈에 관심이 있는 것으로 나타났다.

그 밖에는 100위 내에 ‘여성', ‘식품', ‘자원', ‘독일', ‘프로그램', ‘체험', ‘농산물', ‘미래’, ‘전략', ‘투자, ‘과학’, ‘건설' ‘활성', ‘협동조합’, ‘전문’ ‘육성’, ‘행정,'구축 ‘등이 포함되었다. 즉 독일의 통

6) 뉴시스(Newsis)는 대한민국의 민영 뉴스통신사이다. 
일에 대한 프로그램 체험이 관심 이슈로 나타났다. 그리고 북한의 여성 식품, 농산물, 과학, 건설, 자원 등에 대한 활성화 투자 미래전략을 위하여 협동조합 체제의 전문적인 육성 행정시스템 구축 에 관심을 갖고 있는 것으로 나타났다. 2020년 3월 5일자 노동신문에서는 북한 청년들이 된장 개발 자, 연구사가 되어 상품을 개발한다고 하였다.7) 또한, 북한의 화장품 개발에서도 속도를 내고 있다 고 하였다. 이 분야에 대한 남북한의 상호 경제협력 투자에는 대중의 관심 트랜드가 존재하기 때문 에 서로 간에 수익을 창출할 수 있는 관심 사업이 될 수 있을 것이다.

\section{2 워드 클라우드 시각화 결과}

시각화 분석에서는 통일경제협력에 관한 워드 클라우드, 네트워크 차트, 에고 네트워크, 매트릭 스 챠트 등이 표현된다. 워드클라우드 시각화에서는 단어의 크기가 클수록 언급이 많이 되었다는 뜻을 나타내고 있으며, 빈도수 상위 50개 단어 중에서 30개 단어를 선택하여 시각화하고 있다.8) $<$ 그림 2>은 통일경제협력에 관한 워드 클라우드를 표현하고 있다.

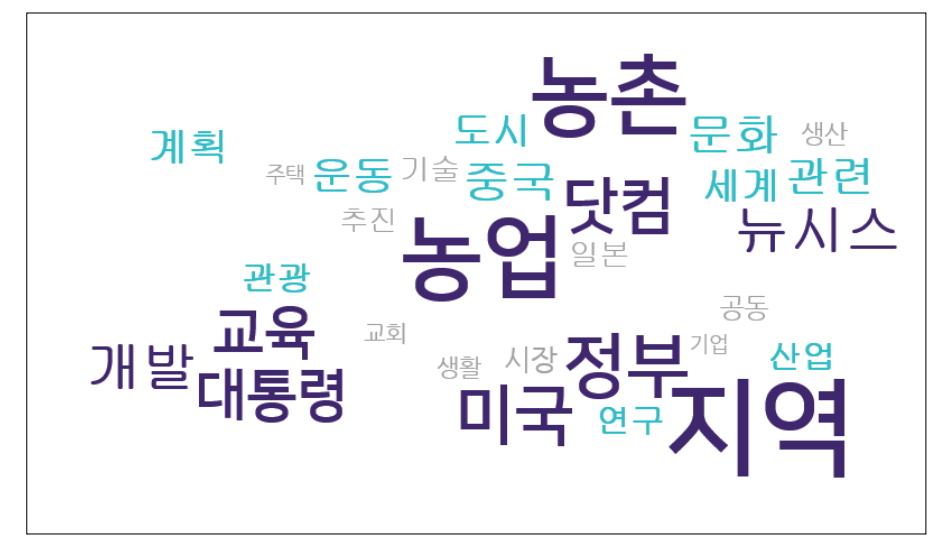

$<$ Figure 2> Visualizing text analysis results with wordcloud

워드 클라우드는 단어의 크기가 클수록 소설 네트워크에서 그 단어에 대한 사용이 많이 표현되 었다는 의미를 나타낸다.9) Figure 2와 같이, 워드 클라우드 차트는 농업, 농촌, 지역 등의 단어에 대하여 가장 크게 나타났다. 이 결과는 북한의 농촌 지역에 대한 농업에 관심 이슈를 표현하고 있 다. 또한, 미국, 정부, 대통령, 개발, 뉴시스 등이 비중을 차지하고 있다. 소셜 네트워크 사용자들은 통일 경제협력에 대한 한 - 미 대통령의 북한 개발 내용의 뉴시스 미디어 전달에 관심을 가지고 있

7) 김영희(2020). 김정은 집권 이후 북한의 '시장형 경제' 실태. 한백통일경제연구. 창간호, p. 30.

8) The IMC(2021). TEXTOM 매뉴얼, V5.0, p. 51.

9) The IMC(2021). TEXTOM 매뉴얼, V5.0. 
는 것이다. 그리고 교육이라는 단어가 중심비중에 포함되어 있다. 정책적인 입장에서는 소셜 네트 워크 사용자들이 관심을 가지는 북한 경제협력에 대한 교육 정책을 반영하는 것이 유용할 것이다. 이러한 관점에서 통일교육이 기존의 안보적 통일 교육에서 평화 - 사회통합 교육으로의 전환이 필 요하다(Cho, S. T., 2021).

\section{3 네트워크 차트 시각화 결과}

네트워크 차트는 빈도가 높을수록 굵은 화살표로 표시된다. $\mathrm{A} \rightarrow \mathrm{B}$ 일 경우, $\mathrm{A}$ 가 출현했을 때 높 은 빈도로 $\mathrm{B}$ 가 연쇄적으로 출현한다는 것을 설명한다. 텍스톰(Textom) 프로그램은 빈도수가 높은 50 개의 단어 쌍에 대한 매트릭스 시각화를 실행하고 있다.10) 서로 관련성이 있는 단어들은 네트워 크로 연결되어 표현된다. 화살표가 크고 진하게 나타나면, 다른 단어들 보다 관련 네트워크가 많다 는 것을 나타낸다(Figure 3).

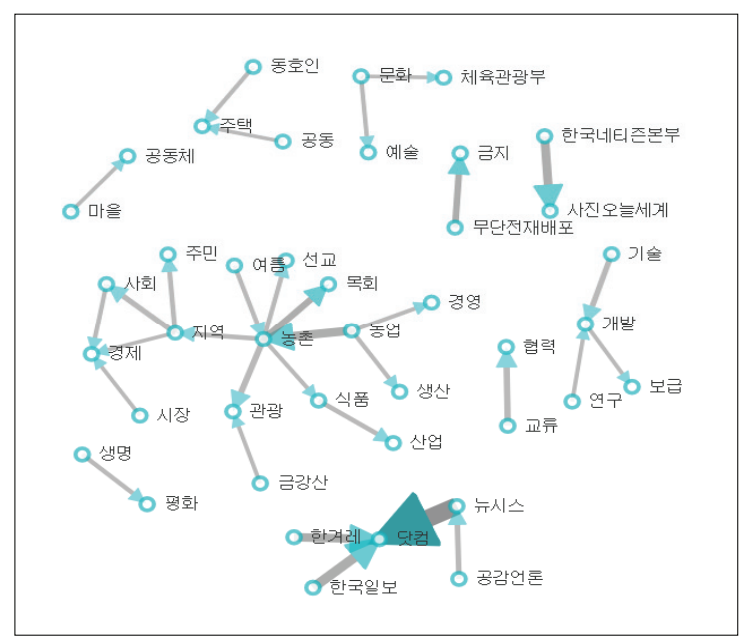

$<$ Figure 3> Visualizing network chart

Figure 3에서 보는 바와 같이, 통일경제협력 네트워크 차트에서는 한겨례, 뉴시스, 공감언론, 한 국일보 등의 닷컴 사이트의 연결고리가 가장 높게 나타났다. 소셜 네트워크 이용자들이 통일경제협 력에 대한 궁금증에 대하여 이 매체들을 많이 활용한다는 것을 나타낸다. 한국네티즌본부 $\rightarrow$ 사진 오늘세계, 무단전자배포 $\rightarrow$ 금지 등의 연결고리가 높게 나타났다. 네티즌들은 오늘의 세계에 대한 사진에 관심을 보이며, 이러한 정보의 무단 배포에 신경을 쓰고 있다는 것을 나타낸다.

네트워크 차트는 농촌 지역과 관련된 많은 연결고리가 형성되어 있다. 통일 경제협력을 위해서 
는 농촌식품 산업, 농촌관광, 농업 생산 등에 의한 농촌 지역의 시장경제사회에 소셜 네트워크 이용 자들의 관심이 높게 나타났다. 북한의 경제난과 식량난이 심각한 상황에서 국민합의에 의한 농업 분야의 개발협력 중심의 추진이 제기되었다.11) Park(2019)은 지속가능한 남북경제협력 방안으로 북한 전역에서 남북경협을 추진해 ‘전국토의 공장화’를 실현시켜야 한다고 하였다. 농업식품 산업 과 관련된 농업 생산 추진 방안이 ‘전국토의 공장화’를 실현하면서 소셜 네트워크 이용자 관심도를 상승시키는 방안이 유용할 것이다.

또한, 북한의 농촌이 목회 및 선교 단어와 연결되어 민간차원에서의 어떻게 이루어지고 있는지 에 관심을 표현하고 있다. 농업개발협력을 위해서 지방자치단체나 민간단체와의 유기적인 역할분 담과 협력을 통해 효과적으로 추진할 수 있다는 분석결과와 동일하다.12) 이 연구에서는 국제 및 국 내의 민간단체의 농촌 개발 지원사업에 대하여 설명하였다. 그리고 동호인 $\rightarrow$ 주택, 공동 $\rightarrow$ 주택, 마을 $\rightarrow$ 공동체 교류 $\rightarrow$ 협력 등의 단어 연결성이 나타났다. 동호인 공동체들이 북한 마을에 대한 공동의 주택 교류 협력 방향을 생각하고 있다는 것을 나타낸다. 사회적 경제기업을 통한 남북협력 모델을 우리 마을 집수리센터, '따릉이' 자전거 통합운영시스템, 마을재생과 이웃이 함께 사는 사회 주택 건설, 마을 공동 작업장 운영, 평양 에너지전환마을 프로젝트 등으로 제안하였다.13)

문화 $\rightarrow$ 예술, 문화 $\rightarrow$ 체육관광부 등이 연결성으로 나타나고 있다. 체육관광부의 예술문화가 계 속적으로 관심의 대상이 되고 있음을 나타낸다. 본 연구는 통일 경제협력이 주제임에도 불구하고 남북의 문화예술에 대한 단어가 도출되었다. 체육관광부는 북한의 경제협력과 연결된 문화 및 예술 에 대한 관심을 가질 필요가 있다. 그리고 기술, 연구, 개발, 보급 등이 하나의 연결성을 유지하고 있다. 북한 경제협력을 위한 기술개발, 연구개발 등이 어떻게 보급되고 있는지에 관심을 나타내고 있다. 현재의 보급지원 위주의 관점이 통합된 프로세스 관점으로 남북이 함께 기술이 연구되고 개 발되는 하나의 프로세스 정책 실행의 전환이 필요하다.

\section{4 에고 네트워크 시각화 결과}

에고 네트워크는 특정한 노드를 중심으로 관련된 다른 노드 간의 연결을 표현한 네트워크로써 이를 통해 내재된 구성노드들 간의 특성을 기술하고 파악하는데 사용된다(Oh, Lee, \& Jun, 2015). 사이즈가 클수록 높은 출현빈도, 작을수록 낮은 출현빈도를 뜻한다. 그리고 원 챠트가 중심 키워드 와 가까이 있을수록 동시 출현빈도가 높다는 것을 표시한다.14) 즉 관련성이 높다는 것을 표현하는

11) 권태진, 김영훈, 지인배(2007). 남북한 농업개발협력 추진 방안 연구, 한국농촌경제연구원 연구보고, p. 156. http://library.krei.re.kr/pyxis-api/1/digital-files/605ba745-9b3f-2a94-e054-b09928988b3c

12) 권태진, 김영훈, 지인배(2007). 남북한 농업개발협력 추진 방안 연구, 한국농촌경제연구원 연구보고, p. 155.

13) 사회적 경제, 남북을 잇다. 평양에 사회적 기업이 진출한다면? 남북도시협력의 새로운 상상, IIFE IN 시선, https://www.lifein.news/news/articleView.html?idxno=10688.

14) The IMC(2021). TEXTOM 매뉴얼, V5.0, p. 53. 
것이다(Figure 4).

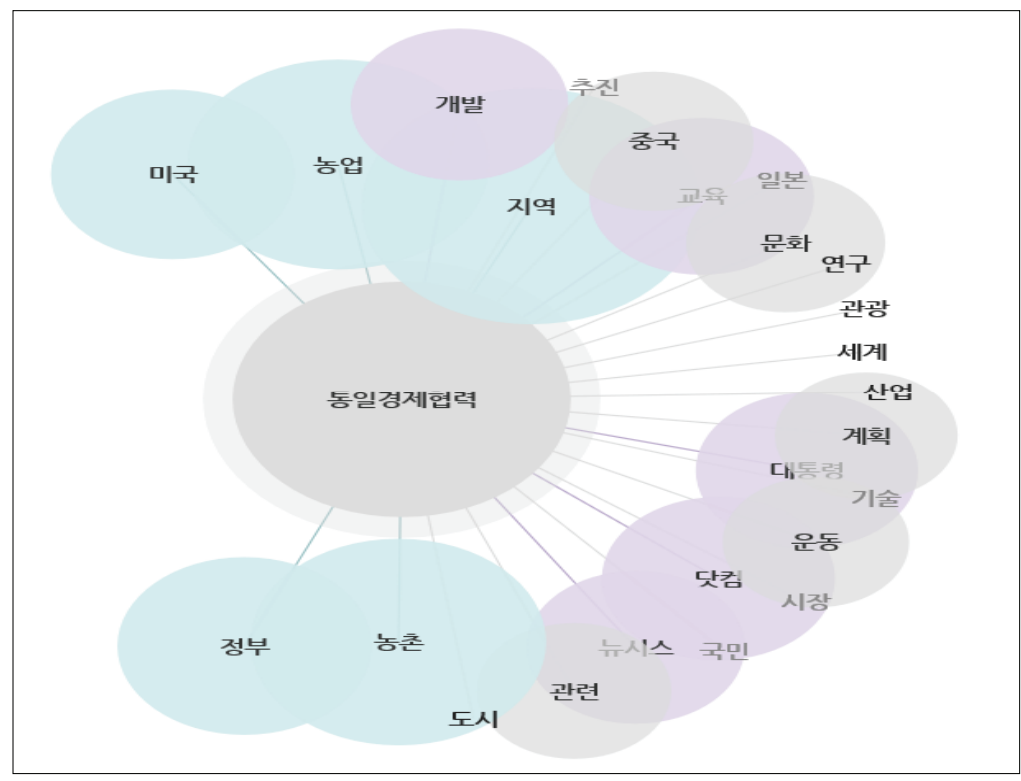

$<$ Figure 4> Visualizing ego network

주제 단어인 통일경제협력을 중심으로 미국, 농업, 지역, 정부, 농촌 등이 동시출현 빈도가 높게 나타났다(Figure 4). 통일경제협력에 대한 에고 네트워크는 통일경제협력을 중심으로 어떠한 이슈 들이 비중 높은 관련성을 지니고 있는지를 파악하기 위하여 제시하였다. 지역이 가장 크게 표현되 어 있다. 즉 소셜 네트워크 이용자들은 미국과 정부의 통일 경제협력을 위한 북한의 농촌 지역 농 업 개발과 교육 추진 정책에 최우선적인 관심을 높게 가지고 있다는 것을 나타낸다. 정부는 오랜 기간 동안 농업의 다양한 분야에서 지원사업을 실시하였다. 북한의 농업개발을 위해서는 지원도 중 요하겠지만, 적극적인 농업 교육이 필요한 것이다. 프랑스와 스위스의 국제자선단체에서는 1999 년 부터 북한의 농업개발에 대한 교육 사업을 실행하기도 하였다.15)김정은 시대에는 인민생활과 관련 된 농림어업 부문의 활성화에 관심을 가지고 있어16) 상호협력투자가 가능할 것이다. 특히 경공업 과 농업 생산물 중 일부는 내수를 넘어 해외시장 판촉에 나서고 있다. 이와 함께 생산 및 포장 공정 등의 설비, 원료 및 자재, 농기계 및 수송기계의 국산화가 추진되고 있다(Lee, Y. H., 2019, p. 61).

산업, 기술, 시장, 문화 등에 관한 연구가 중국과 일본, 대통령 등에서 어떻게 움직이고 있는지에 대하여 관련 닷컴, 뉴시스, 대중여론 등을 통하여 관심 깊게 확인하고 있는 것으로 나타났다. 이러

15) 권태진, 김영훈, 지인배(2007). 남북한 농업개발협력 추진 방안 연구, 한국농촌경제연구원 연구보고, p. 74.

16) 임강택, 홍제환, 양문수, 이석기(2018). ‘하나의 시장 형성을 위한 시장친화적 남북경제협력 방식의 모색. KINU 연구총서 18-10, p. 71. http://www.kinu.or.kr/pyxis-api/1/digital-files/7d612cd5-2827-4e37-8756-37ce25d961ea 
한 관점에서 $\operatorname{Park}(2019)$ 은 북한을 제2의 중국(Next China)으로 선언하고, 중국이 미국으로 수출하 는 5,000억 달러 이상의 소비재를 북한에서 생산해야 한다는 것을 강조하기도 하였다. 또한 정부 입장에서는 통일 경제협력에 대하여 소셜 네트워크 이용자들이 많이 활용하는 언론 및 미디어의 적극적인 참여에 노력하면 더욱 유용할 것이다.

\section{5 메트리스 챠트 시각화 결과}

매트릭스 차트는 매트릭스 데이터(공출현 빈도)의 결과값을 사용한다.17) Figure 5에서는 통일 경제협력 관련 주요 키워드 데이터들이 전체 네트워크 시각화되어 나타나 있다. 네트워크란 복수의 사람 - 조직 - 사물 등을 연결시키는 일정의 관계를 의미하며, 네트워크를 형성하고 있는 사람·조 직 - 사물 등을 액터(actor)라고 한다.18)

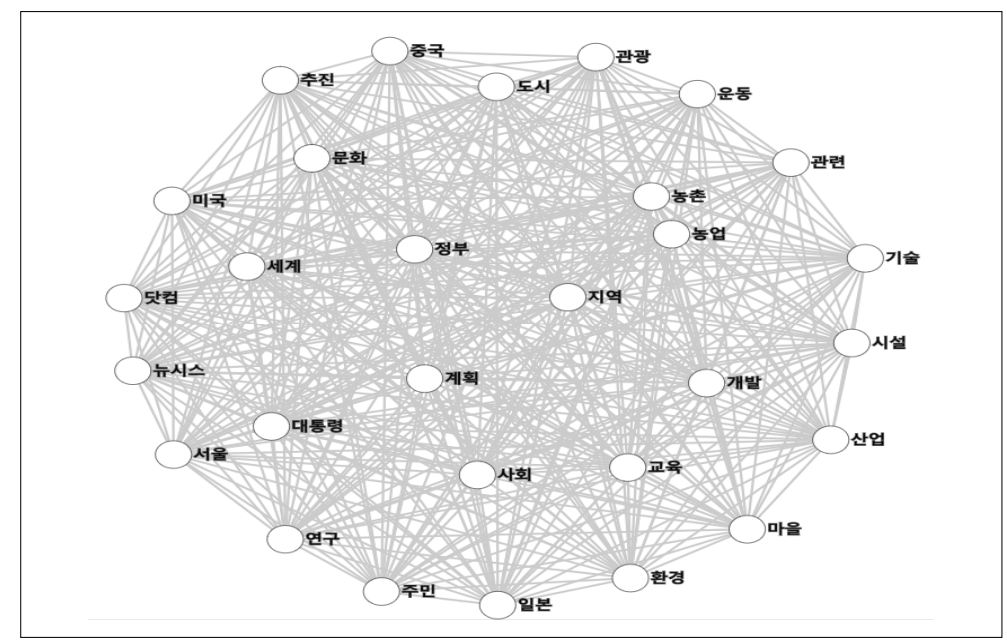

<Figure 5> Visualizing matrix network

Figure 5에서 보는 바와 같이, 네트워크의 중심에는 '정부', ‘지역', ‘계획' 등이 존재하고 있다. 소셜 네트워크 이용자들은 통일 경제협력을 위해 북한 전체에 관한 협력보다는 정부가 어떠한 지 역을 선정하는지에 대한 계획방법에 관심을 두고 있다. 현재 폐쇄되었으나 개성공단 지역 사업계획 에 관한 관심이 높았던 것이 그 예시가 될 것이다.

하지만 전체 네트워크 시각화를 네트워크 차트 및 에고 네트워크 등과 함께 비교하면, 통일 경제 협력을 위한 지역이 정부가 계획한 개성공단뿐만 아니라 농촌 지역을 추가하여 실행하였으면 더욱

17) The IMC(2021). TEXTOM 매뉴얼, p. 56.

18) 21 세기 정치학대사전. 
관심을 불러일으켰을 것으로 판단된다. 특히 2020년 이후, 경색된 남북관계에서는 농촌 지역의 농 산물 관련 사업에 의한 경제협력이 대중의 기초생활 필수품이기 때문에 개성공단과 금강산관광 등 과 같이 완전 금지가 쉽지 않을 것이라고 판단된다. 그럼에도 농업 분야는 남북 경제협력 연구에서 제외되는 경우가 존재한다. 예를 들어, Lee, S. K. et al.(2016)은 통일을 대하여 남북한 산업협력 사 업을 철강 및 화학 분야의 소재 산업, 일반기계 - 자동차 - 조선 등의 기계 산업, 정보통신기기 및 가전 분야 산업, 섬유-의류 및 생활용품산업 등으로 분류하여 구체적으로 분석하였다. 하지만 농 업분야에 대한 내용이 포함되지 않았다.

\section{$\mathrm{V}$. 결론}

과거 70년 동안 남북 관계는 정치적 상황에 따르는 정부 정책에 따라 협력과 경색을 반복했다. 남북 경제협력도 동일했다. 최근에는 비핵화 경제협력에 대한 북미 정상회담 결렬에 따라 경색단계 로 변화되었다. 하지만 남북 경제협력에 의한 교류는 지속되어야 한다는 것이 일반적인 의견이다 (Lee, J. H., 2018; Na \& Jang, 2017; Yang, 2019).

통일경제협력은 대중들이 관심이 높은 분야에서 남북이 상생할 수 있는 산업을 선택하여 지속적 으로 실행되는 것이 유용하다. 그리하여 통일경제협력에 관한 다양한 연구가 분석되었다. 그 연구 들은 이론연구, 실태조사, 설문조사 등이 주류를 이루고 있다. 하지만 다수의 대중에 의한 연구는 미흡한 실정이다. 그리하여 본 연구에서는 소셜 네트워크 이용자들의 관심 이슈를 포함하는 빅데이 터에 의하여 통일경제협력에 관한 관심 트랜드를 시각화 분석하였다. 그 결과, 첫째, 소셜 네트워크 이용자들은 미국과 정부에 의한 북한의 지역 농업 계획과 교육에 관심을 갖고 있었다. 또한, 북한 농촌이 목회 및 선교 단어와 연결되어 존재하였다. 이것은 민간차원에서 농촌 지역 투자개발이 어 떻게 협력되고 있는지에 대한 관심이 존재하는 것이다.

둘째, 동호인 $\rightarrow$ 주택, 공동 $\rightarrow$ 주택, 마을 $\rightarrow$ 공동체 교류 $\rightarrow$ 협력 등의 단어들이 연결성을 이루 어 동호인 공동체에 의한 북한 마을 주택 교류 협력에 관심 이슈가 존재하였다. 김정은 시대에는 사실상의 주택사유화19)가 이루어지고 있는 환경이기 때문에 소셜 네트워크의 관심 이슈 실행 계기 가 될 수 있을 것이다. 이와같이 민간차원의 북한 마을의 주택 건설을 확장해 볼 필요가 있다. 셋째, 빅데이터 분석의 주제가 통일경제협력이었지만 문화 및 예술에 관심을 가지고 있었다. 북한의 경제 협력과 연결된 문화 및 예술의 연결고리 경제협력을 찾아 실행하는 것이 유용할 것이다. 넷째, 기 술, 연구, 개발, 보급 등의 단어가 관심 이슈로 도출되었다. 이 결과는 통합적인 프로세스 관점에서 남북 모두에게 경제적 이익으로 추구될 수 있도록 실행하는 방법이 대중에게 관심사항이라는 것이다.

19) 임강택, 홍제환, 양문수, 이석기(2018). ‘하나의 시장 형성을 위한 시장친화적 남북경제협력 방식의 모색. KINU 연구총서 $18-10$, p. 74. 
다섯째, 소셜 네트워크 이용자들은 닷컴 사이트(한겨례, 뉴시스, 공감언론, 한국일보 등)의 내용 에 관심을 두고 있었다. 이러한 닷컴 사이트에 의한 통일경제협력 홍보가 중요하다는 것을 알 수 있다. 대중들이 관심을 가지는 통일경제협력 내용이 홍보되어야 할 필요성이 있다. 하지만 본 연구 에서 통일경제협력에 대한 빅데이터를 조사한 결과는 데이터 검색 단어가 모두 4,374개로서 다른 소셜 네트워크상의 주제 단어에 비하여 상대적으로 적은 것으로 나타났다. 정부와 관련 부서는 통 일경제협력에 대한 적극적인 홍보로 대중적인 동의를 구하는 것이 필요할 것이다. 여섯째. 기존의 설문조사에 의한 연구는 연구자가 구성한 설문응답에 의존하여 대중의 자유로운 관심 내용을 파악 하기가 어려웠다. 본 연구에서는 소셜 네트워크에서 대중들이 통일경제협력에 대하여 검색한 내용 을 바탕으로 하였다. 따라서 연구자가 아닌 대중들 관점에서의 의견이 포함되어 있다고 할 수 있다.

독일 통일에는 교류와 협력이 중요한 역할을 했다. 동서독은 분단 초기부터 장벽이 세워진 이후 에도 해마다 7,000명에서 3만여 명이 동독에서 서독으로 합법적으로 이주했다.20) 하지만 현재의 남 북한은 불가능하다. 그리하여 정부는 정부 관점의 전략적 통일경제협력 사업을 실행하였다. 그러나 과거 70 년 동안의 정부 주도 통일경제협력은 커다란 진전이 나타나지 않았다. 정부 입장에서는 국 민 대중의 의견을 적극적으로 반영했는지를 파악할 필요가 있다.

즉 남북한 산업협력에 대한 남한 내부의 국민적 공감대 형성도 해결해야 할 과제이다. 이러한 사 업은 대중 관점이기 때문에 서로 간의 심적 동화에 의한 동반자 인식이 이루어지는 장기적인 단계 별 - 점진적 추진으로 계속될 것이다. ${ }^{21)}$ 그러므로 본 연구결과와 같이, 대중의 관심 분야에 대한 내 용을 민간차원에서 적용하며 적극적인 홍보를 하는 방법이 필요할 수 있다. 예를 들어 본 연구결과 의 하나로 농업개발 및 교육 분야에 대한 경제협력이 소셜 네트워크 이용자의 관심사로 나타났다. 농업 분야 경제협력은 가장 기본적인 경제생활이기 때문에 급변하는 상황에서도 지속될 것으로 판 단된다. 북한의 농업 분야 발전은 남한보다 미흡하므로 남한의 농업 기자재 개발 및 수리, 재해지 원, 생산성 향상을 위한 방법 등의 계속 지원, 농산물 상호 개발 등에서 경제협력이 이루어진다면 돌발적인 정치적 상황과는 무관하게 계속될 수밖에 없을 것이다. 이러한 방법은 북한이 남한의 기 본적인 경제생활에 동화되어 가는 행태로 나타날 것이다.

이와같이 민간차원의 통일경제협력은 과거부터 실행한 정부 주도 지원사업을 상호 개발 협력관 점으로 패러다임을 변경시킴으로써 남북한 모두에게 경제적 수익을 낳게 될 것이다. 예를 들어, 농 업 기자재의 남북한 기술협력은 남북한에 농산물의 증가로 인한 수출과 연결되어 수익가치를 창출 할 것이고, 남한의 핵심 농업기술과 기자재 제공은 남북의 경색 상황과 무관하게 민간차원에서 북 한에게 필수적인 요소로 위치할 것이다. 이것은 북한 대중들에게는 기본적 생활의 관심 분야로 지 속적으로 관계가 될 수 있을 것이다. 물론 이 방법은 정부의 간접적인 지원이 수반돼야 할 것이다.

20) 2021 통일문제 이해, 국립통일교육원, p. 23. https://www.uniedu.go.kr/uniedu/home/pds/pdsatcl/view.do?id=20505\&mid= SM00000532

21) 홍순직(2020). 김정은 시대의 남북한 산업협력 방안. 한백통일경제연구, 창간호, p. 138. 
본 연구에서는 소셜 네트워크상의 남한 대중들에 의하여 검색된 빅데이터에 한정되었다. 북한의 인터넷 접근이 불가능하기 때문이다. 따라서 본 연구의 결과는 민간차원에서 남북경협으로 북한에 제시하는 사업으로 활용하면 유용할 것이다. 본 연구에서 활용된 분석도구에서는 무단전재배포 등 의 단어가 웹상의 텍스트 수집에서 사전 정제 작업이 되지 않아 최빈도 단어로 고려되어 나타날 수도 있는 한계가 존재할 수도 있을 것이다.

\section{Acknowledgements}

We would like to thank Editage (www.editage.co.kr) for English language editing.

\section{Declaration of Conflicting Interests}

The author(s) declared no potential conflicts of interest with respect to the research, authorship, and/or publication of this article. 


\section{Reference}

Baran, R. J. (2011). Social networking in China and the United States: Opportunities for new marketing strategy and customer relationship management. AFBE Journal, 4(3), 464-481. https://www.academia.edu/download/19388226/afbejournal-issue8vol4no3.pdf\#page=30

Byun, J. Y., \& Park, Y. B. (2016). A Guiding System of Visualization for Quantitative Bigdata Based on User Intention. KIPS Transactions on Software and Data Engineering, 5(6), 261-266. https://doi.org/10.3745/KTSDE.2016.5.6.261

Cho, S. T. (2021). Makes a Better Future for Korea. Gyeonggi Research Institute: Issues \& Diagnosis, 450, 1-21. https://ibrary.gri.re.kr/download.do?gs_gubun=pms\&filename= 0111311100/20210151/Issue2021-450.pdf

Choe, G. S., Ham, Y. G., \& Kim, S. H. (2013). Bigdata visualization. Korean Society of Computer Information, 21(1), 33-43. https://www.koreascience.or.kr/article/JAKO201329438850422. page

Hwang, U. S. (2017). The Analysis of Interest Trend of Maritime Tourism by Big Data. Journal of Hotel \& Resort, 16(3), 125-145. https://www.kci.go.kr/kciportal/ci/sereArticleSearch/ ciSereArtiView.kci?sereArticleSearchBean.artild=ART002256771

Hwang, U. S. (2018a). The Analysis of Big Data Visualization for Consumer Interest Tendency to YangYang Internationl Airport. Journal of Hotel \& Resort, 17(1), 27-43. https://www.kci.go.kr/kciportal/ci/sereArticleSearch/ciSereArtiView.kci?sereArticleSearc hBean.artiId=ART002323825

Hwang, U. S. (2018b). The Analysis of Big Data Visualization for Consumer Interest Trend to Incheon Internationl Airport. Journal of Hotel \& Resort, 17(3). 161-176. https://www.kci.go.kr/kciportal/ci/sereArticleSearch/ciSereArtiView.kci?sereArticleSearc hBean.artild=ART002382728

Keim, D., Qu, H., \& Ma, K. L. (2013). Big-data visualization. IEEE Computer Graphics and Applications, 33(4), 20-21. https://doi.org/10.1109/MCG.2013.54.

Kim, B. S., Ryu, J. H., Jun, M. S., Kang, J. W., Kim, K. N., Kim, T. D., \& Yu, Y. S. (2018). An Essay on the New Economic Landscape for Gangwon Province in Relation to the New Economic Landscape for the Korean Peninsula. Research Institute for Kangwon, Research paper 18-38, 1-308. http://pms.rig.re.kr/RPMS/Resource/AttachDownHP.ashx?PARAM= QQBBADAAMAAwADAAMAAwADUANAA2ADgAJgAxAA== 
Kim, J., \& Lee, S. (2020). An emerging online social network and disaster-induced collective stress. Media Psychology, 23(4), 521 - 551. https://doi.org/10.1080/15213269.2019.1609989

Kim, P. L., \& Choi, K. H. (2012). Comparative Analysis of Attitudes toward the Unification of North and South Korea. Journal of Peace and Unification Studies, 4(1), 101-139. I410-ECN-0102-2012-340-003127924 https://s-space.snu.ac.kr/bitstream/10371/79156/1/ 04.pdf

Lee, G. Y., Kim, D. Y., Lee, Y. J., Lee, C. L. Song, M. Y., Lee, S. L., Kang, C, G., Cho, J. K., Lee, E. H., Kim, H. S., Lee, S. W., Han, S. H., Choi, M. E., Jeong, S. Y., Chung, B. S., Kim, W., Chang, N. R., Yeo, M. G., Chung, H. Y., \& Choi, C. G. (2019). A Study on Environmental Cooperation between South and North Korea in Gyeonggi-Do. Gyeonggi Research Institute, Policy Study 2019-33, 1-305. https://library.gri.re.kr/download.do?gs_ gubun=pms\&filename=0111212100/6503/F2019-33.pdf

Lee, J. H. (2018). The Study on the Perception for Resumption the tours to Mt. of Geumgang to Strengthen Interchange Cooperation between South and North Korea. Journal of Tourism and Leisure Research, 30(12), 77-92. https://doi.org/10.31336/JTLR.2018. 12.30.12.77

Lee, S. K., Kim, K. Y., Kim, C. G., Nam, J. K., Park, K. S., Park, H., Lee, K. S., Lee, Y. J., Chung, Y. M., Hong, S. I., Shim, Y. S., \& Lee, S, Y, (2016). Strategies and Action Plans for Industrial Cooperation between South and North Korea in Preparation for Unification. Research report 2016-805, 1-326. https://ibrary.kiet.re.kr/CORE/?moduleName= core.KrmsSearchDetail\&control_no=40909

Lee, Y. H. (2019). A Review of Inter-Korean Economic Cooperation from the Perspective of Peace and Innovation. Unification Policy Studies, 28(1), 51-80. https://doi.org/ 10.33728/ups.2019.28.1.003

Na, Y, W., \& Jang, S. H. (2017). The External Opening Policy in Kim Jong-un's Era and Inter-Korean Cooperation: A Search for New Model of Economic Cooperation through North Korea's Economic Development Zones Strategy. THE JOURNAL OF PEACE STUDIES, 18(4), 277-302. https://www.kci.go.kr/kciportal/ci/sereArticleSearch/ ciSereArtiView.kci?sereArticleSearchBean.artild=ART002306310

Oh, I. K., Lee, T. S., \& Jun, C. M. (2015). A Study on Awareness of Korea Tourism through Big Data Analysis. Journal of Tourism Sciences, 39(10), 107-126. https://doi.org/ 10.17086/JTS.2015.39.10.107.126

Park, S. K. (2019). A Study of Sustainable Inter-Korean Economic Cooperation Based on the Experience Of Operating Pyeonghwa Motors [Doctoral dissertation]. Korea University, 
Seoul.

Yang, Y. M. (2019). Peace Leadership and the New Economic Initiative of the Korean Peninsula : Focusing on Exchanges and Cooperation between South and North in the Moon Jae-in Government. Korea and Global Affairs, 3(2), 59-86. https://doi.org/10.22718/ kga.2019.3.2.059 
IDAP 광운대항교 방위사업연구소소

2021, Vol. 4, No. 3, 133-152.

\title{
소셜 네트워크 빅데이터 시각화에 의한 통일 경제협력 관련 관심 이슈 분석
}

\author{
황욱선*
}

\section{국문초록}

본 연구의 목적은 소셜 네트워크 이용자 의견 빅데이터를 활용하여 통일 경제협력에 관한 시각화분석 을 함으로써 일반 대중의 직관적인 관심 트랜드를 파악하는 것이다.

“통일경제협력” 빅데이터 자료는 텍스톰(Textom) 분석 도구에 의하여 관련 빅데이터 자료를 추출하고 텍스트마이닝 정제를 실행하였다. 그 결과는 시각화 도형으로 표현되었다. 연구 결과, 첫째, 소셜 네트 워크 이용자들은 미국과 정부에 의한 북한의 지역 농업 계획과 교육에 관심을 가지고 있었다. 또한 북한 농촌이 목회 및 선교 단어와 연결되어 존재하였다. 이것은 남북한 농촌지역 투자개발이 어떻게 협력되고 있는지에 대한 관심이 존재하는 것이다. 둘째, 동호인 $\rightarrow$ 주택, 공동 $\rightarrow$ 주택, 마을 $\rightarrow$ 공동체 교 류 $\rightarrow$ 협력 등의 단어들이 연결성을 이루어 동호인 공동체에 의한 북한 마을 주택 교류 협력에 관심이 슈가 존재하였다. 셋째, 문화 및 예술에 관심을 가지고 있었다. 북한의 경제협력과 연결된 문화 및 예 술의 연결고리 경제협력을 찾아 실행하는 것이 유용할 것이다. 넷째, 기술, 연구, 개발, 보급 등의 단어 가 관심 이슈로 도출되었다. 이 결과는 통합적인 프로세스 관점에서 남북 모두에게 경제적 이익을 가 져올 수 있는 실행 방법이 일반 대중들의 관심사항이라는 것이다. 다섯째, 소셜 네트워크 이용자들은 한겨례, 뉴시스, 공감언론, 한국일보 등의 닷컴 사이트에 대한 내용에 관심을 가지고 있었다. 이러한 닷컴 사이트에 의한 통일경제협력 홍보가 중요하다는 것을 알 수 있다.

주제어 : 통일경제협력, 빅데이터, 동호인 공동체, 닷컴 사이트, 농촌 지역 투자개발 